\title{
Malignant tumors of the nose and paranasal sinuses: a retrospective review of a Portuguese cancer center's experience
}

\author{
L.G. Castelhano' , F.A. Correia', D.F. Raposo ${ }^{2}$, A.H. Campos ${ }^{3}$, M.R. Melo ${ }^{2}$, S.A. Pereira ${ }^{4}$, M.C. Mariano ${ }^{4}$, \\ L. Ferreira ${ }^{5}$, P. Montalvão ${ }^{5}$, M.T. Magalhães ${ }^{5}$ \\ ${ }^{1}$ Department of Otolaryngology, Hospital de Egas Moniz, Centro Hospitalar Lisboa Ocidental R; 126 R. da Junqueira, \\ Lisboa 1349-019, Portugal; \\ ${ }^{2}$ Department of Otolaryngology, Hospital Prof. Doutor Fernando Fonseca; IC19, Amadora 2720-276, Portugal; \\ ${ }^{3}$ Department of Otolaryngology, Hospital CUF Tejo; Av. 24 de Julho 171A, 1350-352 Lisboa, Portugal; \\ ${ }^{4}$ Department of Otolaryngology, Hospital de São José, Centro Hospitalar Universitário de Lisboa Central; R. José António Serrano, \\ Lisboa 1150-199, Portugal; \\ ${ }_{5}^{5}$ Department of Otolaryngology, Instituto Português de Oncologia Francisco Gentil; R. Prof. Lima Basto, Lisboa 1099-023, Portugal
}

Con t a c t s : Luís Guerra Castelhano Imgcastelhano@gmail.com

\begin{abstract}
Introduction. Although uncommon from a population-based perspective, there is considerable morbidity and mortality associated with malignant tumors of the nose and paranasal sinuses.

The objective of this study was to characterize the presentation, risk factors, management and survival of patients with these tumors treated at a single institution.

Materials and methods. We retrospectively reviewed the clinical records of patients with malignancies of the nose and paranasal sinuses diagnosed between January 2010 and December 2014 at a tertiary cancer center. Univariate and multivariate analysis were performed.

Results. Ninety patients were included in the study. Mean age at diagnosis was 62.8 years (range, 2-95 years) and mean follow-up was 44.5 months (range, 2-113 months). The maxillary sinus (33.3 \%) and the nasal cavity (32.2 \%) were the most frequent sites of origin. Squamous cell carcinoma (36.7\%), mucosal melanoma (15.6\%) and adenoid cystic carcinoma (10\%) were the most common histologic subtypes. Surgery was the primary treatment for $86.7 \%$ of patients. Recurrence occurred in 45 patients (50\%). The overall 5-year survival was $39.3 \%$ and disease free-survival was $45.9 \%$. Survival was significantly decreased in non-smokers $(p=0.022)$, T3-4 tumors $(p=0.007)$, positive lymph nodes $(p<0.001)$, nonepithelial tumors $(p=0.036)$ and positive margins $(p=0.032)$. Survival was not affected by surgical approach between endoscopic, open and combined approaches $(p=0.088)$.

Conclusion. Prognosis is poor, with high recurrences and low survival, but clearly histology, location and stage-dependent. Sound oncologic principles, with complete resections and negative margins, result in a better outcome.
\end{abstract}

Key words: paranasal sinuses, squamous cell carcinoma of head and neck, malignant melanoma, endoscopic surgical procedures

For citation: Castelhano L.G., Correia F.A., Raposo D.F. et al. Malignant tumors of the nose and paranasal sinuses: a retrospective review of a Portuguese cancer center's experience. Opukholi golovy i shei $=$ Head and Heck Tumors 2021;11(3): 10-7. DOI: 10.17650/2222-1468-2021-11-3-10-17.

\section{Злокачественные опухоли носа и пазух носа: ретроспективный обзор опыта португальского онкологического центра}

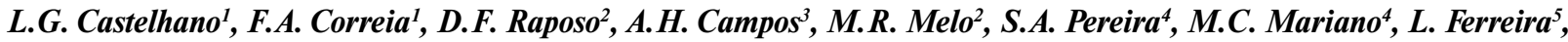 \\ P. Montalvão ${ }^{5}$, M.T. Magalhães ${ }^{5}$
}

'Отделение отоларингологии, Госпиталь им. Эгаша Мониша, Центральный госпиталь Лиссабона; 126 R. da Јипqиеira, Лиссабон 1349-019, Португалия;

${ }^{2}$ отделение отоларингологии, Госпиталь им. Доктора Фернандо Фонсека; IC19, Амадора 2720-276, Португалия;

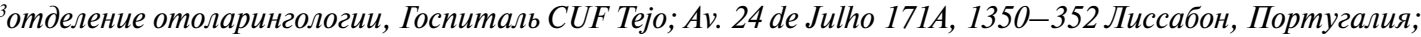


${ }^{4}$ отделение отоларингологии, Госпиталь Святого Иосифа, Центральная больница Университета Лиссабона; R. Jоsé Аntónio Serrano, Лиссабон 1150-199, Португалия;

${ }^{5}$ отделение отоларингологии, Португальский институт онкологии им. Франсиско Джентиля; R. Prof. Lima Basto, Лиссабон 1099-023, Португалия

Кон та кты : $\quad$ Luís Guerra Castelhanolmgcastelhano@gmail.com

Введение. Несмотря на относительную редкость злокачественных опухолей носа и придаточных пазух в общей популяции, показатели заболеваемости и смертности от этой патологии продолжают оставаться на высоком уровне. Цель исследования - анализ течения, факторов риска, лечения и выживаемости пациентов со злокачественными новообразованиями носа и околоносовых пазух, наблюдающихся в одном учреждении.

Материалы и методы. Мы провели ретроспективный анализ историй болезни пациентов со злокачественными опухолями носа и придаточных пазух, которые проходили лечение в одном центре в период с января 2010 г. по декабрь 2014 г. Для обработки данных использовался одно- и многофакторный анализ.

Результаты. В исследование были включены 90 пациентов, средний возраст которых на момент диагноза составлял 62,8 года (диапазон 2-95 лет), а медиана времени наблюдения была 44,5 мес (диапазон 2-113 мес). Чаще всего первичная опухоль локализовалась в гайморовой пазухе (33,3 \%) и полости носа (32,2 \%). 0сновными гистологическими типами опухолей были плоскоклеточный рак (36,7 \%), меланома слизистой оболочки (15,6 \%) и аденоидная кистозная карцинома (10\%). Хирургическое лечение применялось у 86,7 \% пациентов. У 45 (50 \%) больных были зафиксированы рецидивы заболевания. Общая 5-летняя выживаемость составила 39,3 \%, а безрецидивная выживаемость $45,9 \%$. Выживаемость была значительно ниже у некурящих пациентов $(p=0,022)$, больных с опухолями стадии Т3-4 $(p=0,007)$, поражением лимфатических узлов $(p<0,001)$, неэпителиальными опухолями $(p=0,036)$ и положительным краем резекции $(p=0,032)$. Тип хирургического доступа (эндоскопический, открытый или комбинированный) не оказывал влияния на выживаемость $(p=0,088)$.

Заключение. У пациентов с опухолями носа и пазух, как правило, наблюдаются неблагоприятный прогноз, высокая частота рецидивов и низкие показатели выживаемости. Большую роль играют локализация опухоли и стадия заболевания. Применение разумных подходов к лечению, в частности максимально полное удаление новообразования с отрицательными краями резекции, способствует улучшению исходов.

Ключевые слова: околоносовые пазухи, плоскоклеточный рак головы и шеи, злокачественная меланома, эндоскопические хирургические методы

Для цитирования: Castelhano L.G., Correia F.A., Raposo D.F. и др. Злокачественные опухоли носа и пазух носа: ретроспективный обзор опыта португальского онкологического центра. Опухоли головы и шеи 2021;11(3):10-7. (На англ.). DOI: 10.17650/2222-1468-2021-11-3-10-17.

\section{Introduction}

During the last two decades, we have witnessed advances in various fields regarding the diagnosis and treatment of nasal tumors, with new histological classifications, surgical navigation devices and techniques, radiation and chemotherapy modalities [1]. However, prognosis remains generally poor [2]. Although uncommon from a population-based perspective, there is considerable morbidity and mortality associated with malignant tumors of the nose and paranasal sinuses, either due to the disease itself or as a consequence of surgical or nonsurgical treatment [3-6].

These lesions behave similarly to several benign and inflammatory conditions, which often delays diagnosis, resulting in advanced stage disease at presentation. The anatomical complexity of this region and the critical structures commonly involved (specifically the orbit, brain and cranial nerves) add to the troublesome management of these patients [2, 3, 7]. Furthermore, a wide histological variability hinders the comparison of results and the ability to establish standardized treatment protocols [1].

The objective of this study was to characterize the presentation, risk factors, management, and survival of patients with tumors of the nose and paranasal sinuses treated at a single institution.

\section{Materials and methods}

Our study was conducted at the Department of Otolaryngology of the Instituto Português de Oncologia de Lisboa Francisco Gentil, a Portuguese tertiary cancer center, from January to June 2020.

\section{Study protocol}

We retrospectively reviewed the clinical records of patients with malignancies of the nose and paranasal sinuses diagnosed between January 2010 and December 2014. We compiled data regarding demographics (sex, age, occupation), habits (smoking, alcohol consumption), presenting symptoms, tumor characteristics, such as histology (based on the World Health Organization (WHO) Classification of Tumours $4^{\text {th }}$ edition), site, staging (based on the American Joint Committee on Cancer (AJCC) $8^{\text {th }}$ edition on epithelial tumors of the nose and paranasal sinuses and mucosal melanoma); treatment modality, residual or recurrent disease and survival $[8,9]$. The broad variety of surgical techniques and the postoperative complications were not a topic of this study.

As we wanted to evaluate malignancies of the nose as a whole, squamous cell carcinoma (SCC) of the nasal pyramid, orbital tumors with a significant sinonasal component 
and tumors originating from the lacrimal apparatus were also included. Cutaneous melanoma and basal cell carcinoma were excluded because they are traditionally treated in the dermatology department. Nasopharyngeal tumors were also excluded - its etiology is different, in that it originates from epithelial and b-cell interactions, and generally surgery is not the primary treatment due to the relative inaccessibility for a curative resection $[2,10]$.

\section{Statistical analysis}

Follow-up time was defined as the time between initial presentation at this institution for the tumor of interest and the date of the last appointment or death for overall survival (OS). For disease-free survival (DFS), the follow-up time was from the conclusion of treatment for the primary tumor of concern until the date of first recurrence, death, or last contact. Quantitative variables were expressed as mean \pm standard deviations or as median \pm interquartile range for data not normally distributed. Qualitative variables were expressed as absolute values and percentages. KolmogorovSmirnov and Shapiro Wilk normative tests were used to access distribution pattern in quantitative variables. Student's $\mathrm{t}$ test, A-nova one way and respective non-parametric tests, $\chi^{2}$ and proper adjustments were used to relate evaluated variables with primary outcomes (death and recurrence). Kaplan - Meyer curves were determined 5-year OS and DFS and qualitative variables were compared regarding survival. A $p$ value $<0.05$ was considered statistically significant. Statistical analysis was performed using SPSS 24.0 for Windows (SPSS Inc., Chicago, IL, USA).

\section{Results}

\section{Patient characteristics}

Ninety patients were included in the study. Mean age at diagnosis was 62.8 years (range, 2-95 years). 58 (64.4\%) patients were men. $85(94.4 \%)$ patients presented with untreated disease and $5(5.6 \%)$ had persistent disease after previous treatment at another institution. Nasal obstruction $(47.7 \%)$, epistaxis $(37.7 \%)$ and rhinorrhea (33.3 \%) dominated a wide list of presenting symptoms (table 1). Smoking and alcohol consumption were the most common exposures in our sample (50 and $42.2 \%$, respectively). 13 (14.4\%) patients had occupational risk factors ( 3 wood workers, 2 working in the metallurgic industry, 6 construction workers and 2 in the textile industry).

\section{Tumor characteristics}

The most common site of origin was the maxillary sinus, which was seen in 30 (33.3 \%) patients, followed by the nasal cavity in $29(32.2 \%)$ patients. Tumor location is summarized in table 2. In 4 (4.4\%) patients, the sinonasal tumor represented a distant metastasis from another primary cancer 2 adenocarcinomas of the kidney, 1 adenocarcinoma of the breast and 1 cutaneous melanoma. Staging varies according to tumor histology. The WHO recognizes 6 histological groups, each one comprising various different tumors [8]. Histological classification is summarized in table 3. No germ cell or bone and cartilage malignancies were present in this study. SCC (36.7 \%), mucosal melanoma (15.6\%) and adenoid cystic carcinoma $(10,0 \%)$ were the most common histologic subtypes.

Table 1. Presenting symptoms

\begin{tabular}{|l|l|}
\hline \multicolumn{1}{|c|}{ Clinical manifestation } & Number of patients, \% \\
\hline Nasal: & \\
\hline obstruction & 47.7 \\
epistaxis & 37.7 \\
\hline rhinorrhea & 33.3 \\
\hline hyposmia & 5.5 \\
\hline cutaneous pyramidal lesion & 8.9 \\
\hline Facial: & \\
\hline headache & 0 \\
\hline facial swelling & 3.3 \\
\hline V2 hypoesthesia & 2.2 \\
\hline Orbital: & \\
\hline diplopia & 2.2 \\
\hline proptosis & 2.2 \\
\hline scotoma & 1.1 \\
\hline amaurosis & 1.1 \\
\hline epiphora (chronic dacryocystitis) & 1.1 \\
\hline Intracranial: & 1.1 \\
\hline meningitis & \\
\hline Oral: & \\
\hline oroantral fistula & \\
\hline neck: & \\
\hline
\end{tabular}

Staging at presentation for primary epithelial malignancies is summarized in fig. 1a. T4 classification was most common $(40.6 \%)$. Nodal disease was seen at initial presentation in $8(13.6 \%)$ patients and distant metastasis was seen in $2(3.4 \%)$ patients. Staging at presentation for primary mucosal melanoma is summarized in fig. $1 b$. Mucosal melanomas are extremely aggressive, and all lesions are classified as T3 and stage III at a minimum, reflecting a poorer prognosis [9].

\section{Treatment}

Treatment characteristics are summarized in table 4.78 $(86.7 \%)$ patients underwent surgery as their primary modality of treatment. An exclusive external approach was performed in $60(76.9 \%)$ of these patients, while $11(14.1 \%)$ and $7(9.0 \%)$ patients underwent endoscopic and combined approaches, respectively. Pathological analysis for surgical margins found microscopic positive margins in 30 (39 \%) patients, negative in $19(25 \%)$ and not evaluable in $27(36 \%)$. Neck dissection was simultaneously performed in 9 (11.5\%) patients. Adjuvant radiation was administered in 66 patients, 


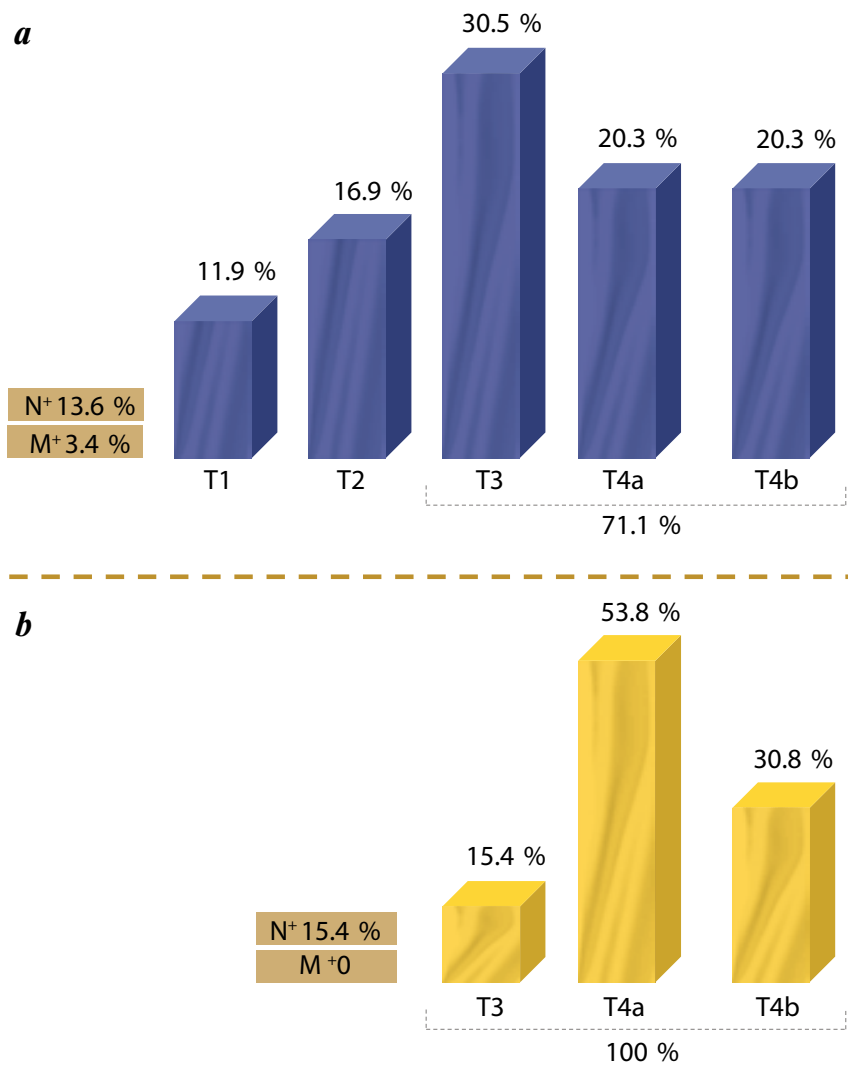

Fig. 1. TNM staging at presentation for epithelial tumors (a) and mucosal melanoma (b). For the latter, all lesions are classified as T3 and stage III at a minimum, reflecting a poorer prognosis

Table 2. Tumor origin

\begin{tabular}{|l|c|}
\hline \multicolumn{1}{|c|}{ Site } & Number of patients, \% \\
\hline Maxillary sinus & 33.3 \\
\hline Nasal cavity & 32.2 \\
\hline Overlapping sites & 15.6 \\
\hline Nasal pyramid & 8.9 \\
\hline Ethmoid sinus & 2.2 \\
\hline Pterygopalatine fossa & 2.2 \\
\hline Orbit & 2.2 \\
\hline Forntal sinus & 1.1 \\
\hline Sphenoid sinus & 1.1 \\
\hline Lacrimal sac & 1.1 \\
\hline
\end{tabular}

with 10 patients receiving concurrent chemoradiotherapy. $11(12.2 \%)$ patients received nonsurgical therapy, with 6 patients receiving external radiation therapy, 3 chemotherapy and 2 concurrent chemoradiotherapy. One patient with mucosal melanoma died before treatment.
Table 3. Histologic classification

\begin{tabular}{|l|c|}
\hline \multicolumn{1}{|c|}{ Group and subtype } & $\begin{array}{c}\text { Number } \\
\text { of patients, } \\
\text { abs. (\%) }\end{array}$ \\
\hline $\begin{array}{l}\text { Epithelial malignancies }(n=62 ; 68.9) \text { : } \\
\text { mucosal squamous cell carcinoma (sinonasal) }\end{array}$ & $33(36.7)$ \\
$\begin{array}{l}\text { adenoid cystic carcinoma } \\
\text { adenocarcinoma } \\
\text { cutaneous squamous cell carcinoma } \\
\text { (pyramidal skin) }\end{array}$ & $9(10.0)$ \\
$\begin{array}{l}\text { neuroendocrine tumors } \\
\text { sinonasal undifferentiated carcinoma } \\
\text { acinic cell carcinoma }\end{array}$ & $7(7.8)$ \\
\hline $\begin{array}{l}\text { Neuroectodermal malignancies }(n=17 ; 18.9): \\
\text { mucosal malignant melanoma } \\
\text { olfactory neuroblastoma }\end{array}$ & $5(5.6)$ \\
\hline $\begin{array}{l}\text { Soft tissue malignancies }(n=7 ; 7.8): \\
\text { angiosarcoma }\end{array}$ & $1(1.1)$ \\
\hline $\begin{array}{l}\text { undifferentiated pleomorphic sarcoma } \\
\text { leiomyosarcoma } \\
\text { rhabdomyosarcoma }\end{array}$ & $3(1.1)$ \\
\hline $\begin{array}{l}\text { Hematolymphoid malignancies }(n=4 ; 4.4): \\
\text { lymphoma } \\
\text { extramedullary plasmacytoma }\end{array}$ & $3(3.3)$ \\
\hline & $2(2.2)$ \\
$1(1.1)$ \\
$1(1.1)$
\end{tabular}

Table 4. Treatment characteristics

\begin{tabular}{|l|c|}
\hline \multicolumn{1}{|c|}{ Modality } & Number of patients, abs. (\%) \\
\hline $\begin{array}{l}\text { Surgery }(n=78 ; 86.7): \\
\text { alone } \\
+ \text { XRT } \\
\text { + chemo + XRT } \\
\text { + chemo }\end{array}$ & $11(12.2)$ \\
\hline $\begin{array}{l}\text { Non-surgical }(n=11 ; 12.2): \\
\text { XRT } \\
\text { XRT + chemo } \\
\text { chemo }\end{array}$ 10(11.1) \\
\hline
\end{tabular}

Note. Chemo - chemotherapy; XRT - external radiation therapy.

\section{Follow-up}

Mean follow-up was 44.5 months (range, 2-113 months). Patients were usually kept under close surveillance for 2 years, with appointments every 3 months, and then every 6 months until 5 years. Residual or recurrent disease was found in $45(50.6 \%)$ patients, with a mean of 9.3 months after primary treatment. Recurrent disease occurred locally in $34(37.8 \%)$ patients, regionally in $9(10.0 \%)$ patients, and distantly in $18(20.0 \%)$ patients. Fig. 2 represents the patterns of treatment failure.

Five-year OS was $39.3 \%$ and DFS was $45.9 \%$. Smokers had a significantly better prognosis compared to nonsmokers $(p=0.022)$, but prognosis was not affected 
by alcohol consumption ( $p=0.739)$ or occupational risk factors $(p=0.472)$. Survival was also location dependent $(p=0.004)$, as tumors located in the nasal pyramid or cavity showed a better prognosis compared to the ones located in the frontal or sphenoidal sinuses, orbit, lacrimal sac and pterygopalatine fossa. Five-year survival was found to be significantly worse in patients with nonepithelial tumors compared to epithelial tumors $(28.6 \%$ and $52.9 \%$, respectively; $p=0.036$; fig. 3 ). $\mathrm{T}$ and $\mathrm{N}$ fractions of TNM staging for epithelial tumors and mucosal melanoma significantly influenced 5-year survival $(p=0.007$ and $p<0.001$, respectively; fig. $4 a$ and $4 b$ ). Although patients with M1 had worse prognosis compared to M0, this was not statistically significant ( $p=0.636$; fig. $4 c)$. While treatment modality significantly influenced survival $(p<0.001)$, surgery did not show a statistically significant impact compared to non-surgical treatments $(p=0.224)$. Open surgical resections did not offer a greater survival benefit compared with endoscopic procedures $(p=0.088)$. Positive surgical margins were associated with lower survival $(p=0.032)$.

\section{Discussion}

Malignant tumors of the nose and paranasal sinuses can occur at any age, but the majority is seen between the $6^{\text {th }}$ and $7^{\text {th }}$ decades of life [11-13]. Pediatric sinonasal malignancies are more likely to be rhabdomyosarcomas [11]. Although most series show a male predominance, this proportion is lower than in the rest of head and neck tumors - probably due to the fact that the classic risk factors of tobacco and alcohol (more frequent in males) do not have such a high carcinogenic potential in the paranasal sinuses when compared the larynx, oropharynx or hypopharynx, where the male predominance is superior to $90 \%$ [1]. Other risk factors have been linked to the development of sinonasal tumors. The most notable is wood dust exposure and the

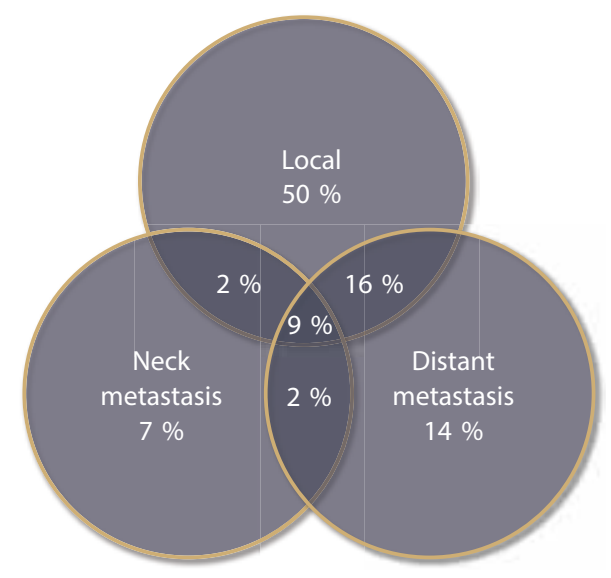

Fig. 2. Diagram illustrating the patterns of treatment failure. Each circle shows the percentage of local, regional (neck) and distant metastasis for the 45 patients who had recurrent disease development of adenocarcinoma. Products of the metal and the textile industries, leather, thorium dioxide and imaging agents are all risk factors for SCC [2].

Because the nasal cavity and the paranasal sinuses are air-filled structures with significant potential space, sinonasal neoplasms rarely produce symptoms at an early stage. Even when symptoms are present, they may be innocuous, such as nasal obstruction, epistaxis, or symptoms of obstructive sinusitis, including facial pain and congestion [14]. Most studies report nasal obstruction as the most frequent presenting symptom $[13,15,16]$.

There is still great debate about the most frequent site of origin for sinonasal tumors. Most studies report either the maxillary sinus or the nasal cavity as the most involved locations, usually followed by the ethmoid sinuses [1, 11-16]. In our series, the ethmoid was an infrequent location (2.2\%), possibly because these tumors easily grow into the nasal cavity, which led many of them to be labeled as overlapping sites $(15.6 \%)$. Excluded from most epidemiological data are metastases to the nasal cavity and the paranasal sinuses which, in our experience, account for a notable portion of malignant tumors encountered at this anatomical site. Breast cancer, prostate cancer and renal cell carcinoma metastases are among the most frequent primaries involved [11, 17-19].

Epithelial tumors and SCC are consistently reported as the most frequent histological group and subtype, respectively. The percentage of SCC given in different studies usually varies between 40 and $50 \%[12,15,20,21]$. The smaller percentage found in our study (36.7 \%) is most likely due to the fact that we also included tumors of the nasal pyramid, the orbit and the lacrimal system, which are typically excluded in the majority of these series. The frequency

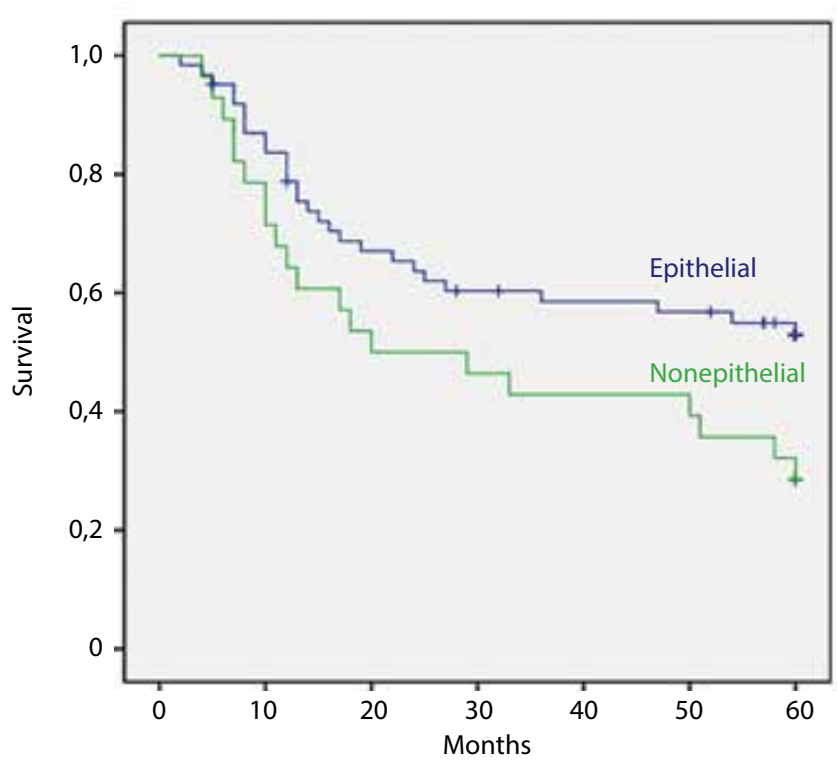

Fig. 3. Kaplan-Meyer curves regarding 5-year survival for epithelial (blue line) and nonepithelial tumors (green line). Epithelial tumors showed better results $(p=0.036)$ 


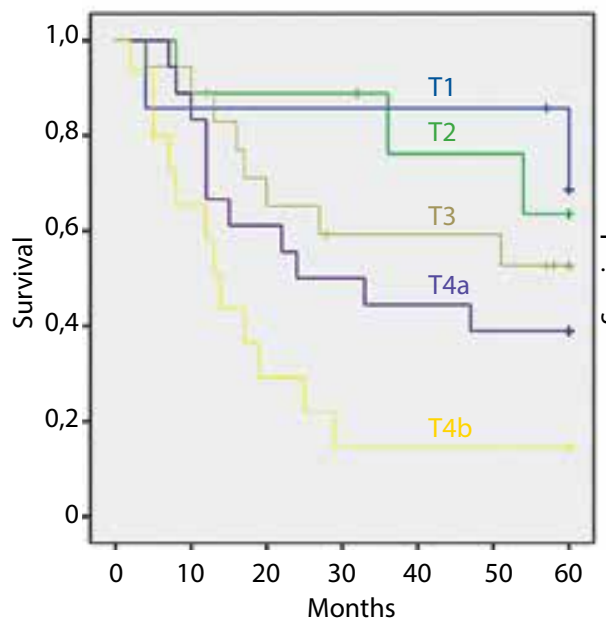

$b$

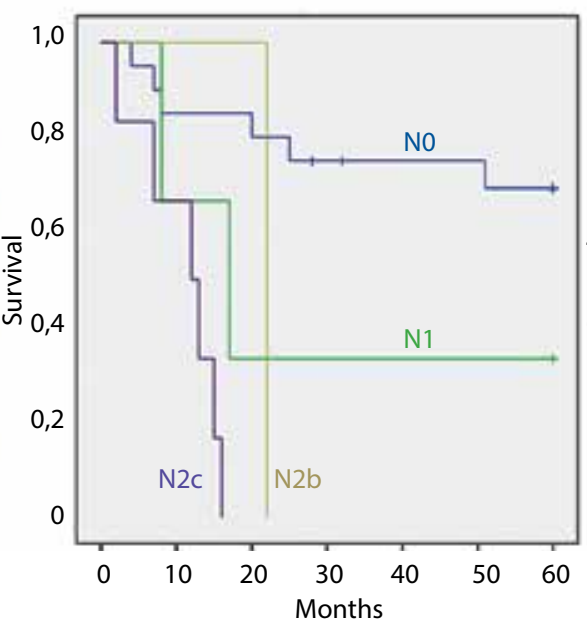

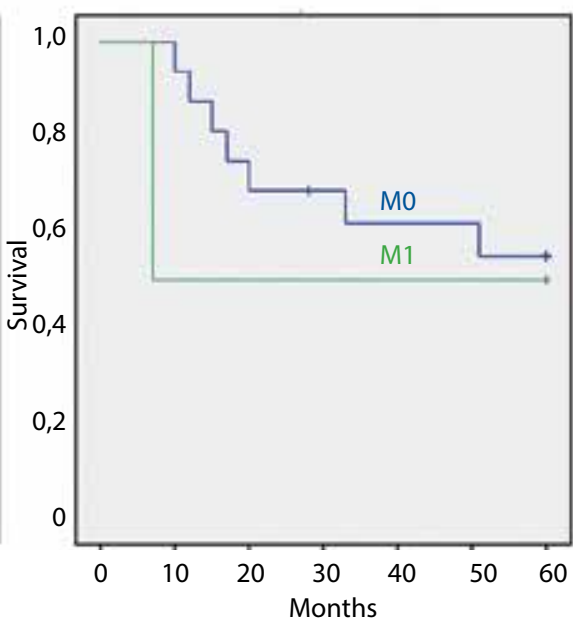

Fig. 4. Kaplan-Meyer curves regarding 5-year survival for the different parcels of the TNM staging for epithelial tumors and mucosal melanoma: a - primary tumor ( $p=0.007) ; b$ - regional lymph nodes $(p<0.001) ; c$ - distant metastasis $(p=0,636)$

of mucosal melanoma was exceptionally high $(15.6 \%)$ when compared to other studies (usually $<10 \%$ ) $[12,15,20]$. We speculate that this may relate to the reality that, while other centers in Portugal may treat and follow-up a significant quota of the non-melanoma malignancies, the aggressiveness of this specific tumor typically elicits a referral to a cancer center.

As we mentioned above, the paucity of symptoms explains the advanced stage at presentation. For epithelial tumors, most patients present with a T3 or T4 lesion [12, 14, 16]. The incidence of nodal and distant disease at presentation varies extensively, but it can go as high as 14.3 and $27 \%$, respectively [11, 13-15, 21]. For nonepithelial and nonmelanoma tumors, other staging systems must be used (e. g., the Lugano classification for lymphomas and the modified Kadish system for esthesioneuroblastomas) [22, 23]. Only recently has the AJCC introduced a staging system for some sarcomas of the head and neck [24].

In concordance with other reports, most patients underwent surgical treatment (ranging from 43.5 to $89 \%$ ) with the modality of choice being surgery and postoperative irradiation (ranging from 47.7 to $76 \%$ ) [15, 21, 25]. Although endoscopic techniques were traditionally not recommended for malignant tumors, more and more studies have proven their effectiveness and safety. Nowadays, they are considered the gold-standard in many centers [26-31]. Although complete resection with negative margins is known to be a critical factor, most studies do not mention the status of surgical margins. A study by M.K. Bhayani et al. and another by I. Ganly et al. mention positive margins in 19.5 and $25 \%$, respectively $[13,32]$.

Recurrent disease reports vary between 45.8 and $65 \%$ [14, 20, 32]. Similarly to most series, local recurrence was the dominant treatment failure. In other studies, 5-year OS ranged from 37.8 to $54.5 \%$ [12, 20, 25, 32, 33]. Tobacco smoke is associated with SCC, which are epithelial tumors and portray a better prognosis [34]. Hence, the association of smokers with a better prognosis.

Different but coexisting theories may explain why location influences survival. Tumor location itself may relate to time of diagnosis, likelihood of tumor spreading to surrounding areas and/or feasibility of surgical access for a safe tumor resection. For example, a pyramidal skin tumor becomes visible at an early stage, leading to an early diagnosis. A tumor growing in the nasal cavity will probably cause some degree of nasal obstruction sooner than one growing in a paranasal sinus. Additionally, a safe resection of these tumors will likely be easier compared to a tumor located at the pterygopalatine fossa or the sphenoid sinus, areas where surgical access is technically more complex and tumor spreading to the infratemporal fossa or intracranially is more likely.

Survival is clearly histology-dependent. Nonepithelial tumors portrayed a poorer prognosis, much do to the high frequency $(15.6 \%)$ and low 5-year OS (28.6\%) of mucosal melanoma. TNM staging has proven to be crucial from a prognostic standpoint, as all $\mathrm{T}$ and $\mathrm{N}$ stages correlated to different outcomes. We suspect the absence of a statistically significant correlation regarding the $\mathrm{M}$ stages was due to the low number of patients presenting with M1 disease. The choice of treatment for sinonasal malignant tumors is dependent, among other factors, on the histological diagnosis and the extent of the tumor [11]. For epithelial malignancies, surgery is generally not recommended for $\mathrm{T} 4 \mathrm{~b}$ or M1 tumors [35]. However, for nonepithelial malignancies such as lymphomas, the combination of chemotherapy and radiotherapy is usually the treatment of choice [11].

\section{Conclusion}

The rarity of these malignancies allied with the marked histological diversity and the vast arsenal of surgical 
techniques described in the literature are all nuances that make outcome comparisons difficult to assess. Prognosis is generally poor, with high recurrences and low survival, but clearly histology, location and stage-dependent. Sound oncologic principles, with complete resections and negative margins, result in a better outcome.

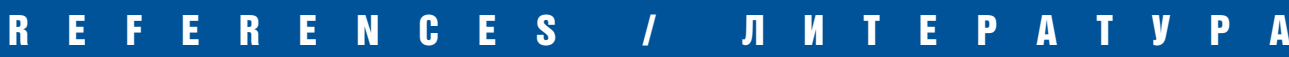

1. Gras Cabrerizo J.R., Sarandeses García A., Montserrat I Gili J.R. et al. Revisión de los carcinomas de senos paranasales. Acta Otorrinolaringol Esp 2007;58(6):266-75. (In Spanish).

2. Harvey R.J., Dalgorf D.M. Chapter 10: Sinonasal malignancies. Am J Rhinol Allergy 2013;27(1 Suppl):S35-8. DOI: 10.2500/ajra.2013.27.3894.

3. Eloy J.A., Svider P.F., Pfisterer M.J. et al. Carcinoma of the nasal cavity and anterior skull base. In: Head and Neck Cancer: Management and Reconstruction. Ed. by E.M. Genden. $2^{\text {nd }}$ ed. New York: Thieme, 2019. Pp. 278-303.

4. Dutta R., Dubal P.M., Svider P.F. et al. Sinonasal malignancies: a populationbased analysis of site-specific incidence and survival. Laryngoscope 2015;125(11):2491-7. DOI: $10.1002 /$ lary.25465.

5. Su S.Y., Kupferman M.E., DeMonte F. et al. Endoscopic resection of sinonasal cancers. Curr Oncol Rep 2014;16(2):369. DOI: 10.1007/s11912-013-0369-6.

6. Turner J.H., Reh D.D. Incidence and survival in patients with sinonasal cancer: a historical analysis of populationbased data. Head Neck 2012;34(6):877- 85 . DOI: $10.1002 /$ hed.21830.

7. Ho A.S., Zanation A.M., Ganly I. Malignancies of the paranasal sinus. In: Cummings Otolaryngology Head and Neck Surgery. Ed. by P.W. Flint, B.H. Haughey, V.J. Lund et al. $6^{\text {th }}$ ed. Philadelphia: Elsevier, 2015. Pp. 1176-201.

8. Tumours of the nasal cavity, paranasal sinuses and skull base. In: WHO Classification of Head and Neck Tumours. Ed. by A.K. El-Naggar, J.K. Chan, J.R. Grandis et al. $4^{\text {th }}$ ed. Lyon: Internation Agency for Research on Cancer, 2017. Pp. 11-60.

9. Nasal cavity and paranasal sinuses. In: AJCC Cancer Staging Manual. Ed. by M.B. Amin, S.B. Edge, F.L. Greene et al. $8^{\text {th }}$ ed. New York: Springer, 2017. Pp. 137-47.

10. Pharynx and Esophagus. In: Jatin Shah's Head and Neck Surgery and Oncology. Ed. by J.P. Shah, S.G. Patel, B. Singh. $4^{\text {th }}$ ed. Phildadelphia: Elsevier, 2012. P. 304

11. Götte K., Hörmann K. Sinonasal malignancy: what's new? ORL J Otorhinolaryngol Relat Spec
2004;66(2):85-97. DOI: $10.1159 / 000077801$

12. Goldenberg D., Golz A., Fradis M. et al. Malignant tumors of the nose and paranasal sinuses: a retrospective review of 291 cases. Ear Nose Throat J 2001;80(4):272-7.

13. Bhayani M.K., Yilmaz T., Sweeney A. et al. Sinonasal adenocarcinoma: a 16-year experience at a single institution. Head Neck 2014;36(10):1490-6. DOI: $10.1002 /$ hed.23485.

14. Nasal cavity and paranasal sinuses. In: Jatin Shah's Head and Neck Surgery and Oncology. Ed. by J.P. Shah, S.G. Patel, Singh B. $4^{\text {th }}$ ed. Phildadelphia: Elsevier, 2012. P. 104.

15. Danesh-Sani S.A., Sarafraz A., Chamani M., Derakhshandeh H. Paranasal sinuses malignancies: a 12-year review of clinical characteristics. Med Oral Patol Oral Cir Bucal 2016;21(5):e626e630. DOI: $10.4317 /$ medoral.21170.

16. Spiro J.D., Soo K.C., Spiro R.H. Squamous carcinoma of the nasal cavity and paranasal sinuses. Am J Surg 1989;158(4):328-32. DOI: 10.1016/0002-9610(89)90127-x.

17. Austin J.R., Kershiznek M.M., McGill D., Austin S.G. Breast carcinoma metastatic to paranasal sinuses. Head Neck 1995;17(2):161-5. DOI: 10.1002/hed.2880170217.

18. Maschka D.A., McCulloch T.M., Nerad J.A. Prostate cancer metastatic to the orbit. Ann Otol Rhinol Laryngol 1996;105(1):70-1. DOI: $10.1177 / 000348949610500113$.

19. Terada T. Renal cell carcinoma metastatic to the nasal cavity. Int J Clin Exp Pathol 2012;5(6):588-91.

20. Harbo G., Grau C., Bundgaard T. et al. Cancer of the nasal cavity and paranasal sinuses. A clinico-pathological study of 277 patients. Acta Oncol 1997;36(1):45-50. DOI: $10.3109 / 02841869709100731$.

21. Tufano R.P., Mokadam N.A., Montone K.T. et al. Malignant tumors of the nose and paranasal sinuses: hospital of the University of Pennsylvania experience 19901997. Am J Rhinol 1999;13(2):117-23. DOI: $10.2500 / 105065899782106698$.

22. Hodgkin and Non-Hodgkin Lymphomas. In: AJCC Cancer Staging Manual.
Ed. by M.B. Amin, S.B. Edge, F.L. Greene et al. $8^{\text {th }}$ ed. New York: Springer, 2017. Pp. 937-58.

23. Dulguerov P., Calcaterra T. Esthesioneuroblastoma: the UCLA experience 1970-1990. Laryngoscope 1992;102(8):843-9. DOI: 10.1288/00005537-19920800000001 .

24. O’Sullivan B., Maki R.G., Agulnik M. et al. Soft tissue sarcoma of the head and neck. In: AJCC cancer staging manual. Ed. by M. Amin, S. Edge, F. Greene et al. $8^{\text {th }}$ ed. New York: Springer, 2017. Pp. 113-21.

25. Koivunen P., Mäkitie A., Bäck L. et al. A national series of 244 sinonasal cancers in Finland in 1990-2004. Eur Arch Otorhinolaryngol 2012;269(2):615-21. DOI: $10.1007 / \mathrm{s} 00405-011-1615-x$.

26. Stammberger H., Anderhuber W., Walch C., Papaefthymiou G. Possibilities and limitations of endoscopic management of nasal and paranasal sinus malignancies. Acta Otorhinolaryngol Belg 1999;53(3):199-205.

27. Meccariello G., Deganello A., Choussy O. et al. Endoscopic nasal versus open approach for the management of sinonasal adenocarcinoma: a pooled-analysis of 1826 patients. Head Neck 2016;38(1 Suppl):E2267-74. DOI: $10.1002 /$ hed.24182.

28. Suh J.D., Ramakrishnan V.R., Chi J.J. et al. Outcomes and complications of endoscopic approaches for malignancies of the paranasal sinuses and anterior skull base. Ann Otol Rhinol Laryngol 2013;122(1):54-9. DOI: $10.1177 / 000348941312200110$.

29. Castelnuovo P., Battaglia P., TurriZanoni M. et al. Endoscopic endonasal surgery for malignancies of the anterior cranial base. World Neurosurg 2014;82(6 Suppl):S22-31. DOI: 10.1016/j.wneu.2014.07.021.

30. Castelnuovo P., Turri-Zanoni M., Battaglia P. et al. Sinonasal malignancies of anterior skull base: histology-driven treatment strategies. Otolaryngol Clin North Am 2016;49(1):183-200. DOI: 10.1016/j.otc.2015.09.012.

31. Nicolai P., Castelnuovo P., Bolzoni Villaret A. Endoscopic resection 
of sinonasal malignancies. Curr Oncol

Rep 2011;13(2):138-44.

DOI: $10.1007 / \mathrm{s} 11912-011-0151-6$.

32. Ganly I., Patel S.G., Singh B. et al. Craniofacial resection for malignant paranasal sinus tumors: report of an International Collaborative Study. Head Neck 2005;27(7):575-84. DOI: $10.1002 /$ hed.20165.
33. Khademi B., Moradi A., Hoseini S., Mohammadianpanah M. Malignant neoplasms of the sinonasal tract: report of 71 patients and literature review and analysis. Oral Maxillofac Surg 2009;13(4): 191-9. DOI: 10.1007/s10006-009-0170-8.

34. 'T Mannetje A., Kogevinas M., Luce D. et al. Sinonasal cancer, occupation, and tobacco smoking in European women and men. Am J Ind Med 1999;36:101-7. DOI: 10.1002/(sici) 1097-0274(199907)36: $1<101$ ::aid-ajim14>3.0.co;2-a.

35. Pfister D.G., Spencer S., Adelstein D. et al. Head and Neck Cancers, Version 2.2020, NCCN Clinical Practice Guidelines in Oncology. J Natl Compr Canc Netw 2020;18(7):873-98. DOI: $10.6004 /$ jnccn.2020.0031

\section{Authors' contribution}

L.G. Castelhano: designed the study, collected and analyzed data, reviewed current literature related to the study, drafted the manuscript;

F.A. Correia: performed statistical analysis;

D.F. Raposo: collected and analyzed data regarding spindle cell carcinomas;

A.H. Campos: collected and analyzed data regarding mucosal melanoma;

M.R. Melo, S.A. Pereira, M.C. Mariano: collected data for analysis, edited the manuscript;

L. Ferreira, P. Montalvão, M.T. Magalhães: participated in the diagnosis, surgical treatment and follow-up of all patients, reviewed the manuscript.

Вклад авторов

L.G. Castelhano: разработка дизайна исследования, сбор и анализ данных, обзор литературы по теме исследования, написание текста статьи;

F.A. Correia: статистический анализ данных;

D.F. Raposo: сбор и анализ данных по веретеноклеточному раку;

A.Н. Campos: сбор и анализ данных по меланоме слизистой оболочки;

M.R. Melo, S.A. Pereira, M.C. Mariano: сбор данных для анализа, редактирование статьи;

L. Ferreira, P. Montalvão, M.T. Magalhães: диагностика, хирургическое лечение и отслеживание пациентов, редактирование статьи.

\section{ORCID of authors / ORCID авторов}

L.G. Castelhano: https://orcid.org/0000-0001-6501-6941

D.F. Raposo: https://orcid.org/0000-0001-9337-0737

S.A. Pereira: https://orcid.org/0000-0002-8341-078X

M.C. Mariano: https://orcid.org/0000-0002-6898-9631

L. Ferreira: https://orcid.org/0000-0001-7268-7495

Conflict of interest. The authors declare no conflict of interest.

Конфликт интересов. Авторы заявляют об отсутствии конфликта интересов.

Financing. The work was performed without external funding.

Финансирование. Работа выполнена без спонсорской поддержки.

Статья поступила: 04.06.2021. Принята к публикации: 18.08.2021.

Article submitted: 04.06.2021. Accepted for publication: 18.08.2021. 